\title{
ИЗ ИСТОРИИ НИЖЕГОРОДСКОГО ОПОЛЧЕНИЯ 1812 Г.: «ВЛАДЕЛЬЧЕСКИЕ» НЕДОИМКИ И ИХ ВЗЬСКАНИЕ
}

\section{FROM THE HISTORY OF THE NIZHNY NOVGOROD MILITIA IN 1812: LANDLORDS ARREARS AND THEIR RECOVERY}

\section{Nikolaev}

F. Dorofeev

Summary: Based on the Archival materials of the Central archive of the Nizhny Novgorod region (TSAN0), this article discusses the specifics of the problem of food and fodder shortages during the formation of units of the Nizhny Novgorod militia in the era of 1812. On the basis of clerical documentation, information is provided on the amount of food that was not delivered, along with data on those landlords who had problems in supplying and providing the militia. The conclusion is made about the unintentional nature of these short deliveries, the cause of which was either incorrect or corrected during the collection of the militia, the initial calculations.

Keywords: Patriotic War of 1812, Nizhny Novgorod militia in 1812, marching march, weapon, equipment, food, forage.

\author{
Николаев Дмитрий Андреевич \\ К.и.н., дочент, Нижегородский государственный \\ университет им. Н.И. Лобачевского \\ dmnikolaeff@mail.ru \\ Дорофеев Федор Александрович \\ К.и.н., дочент, Нижегородский государственный \\ университет им. Н.И. Лобачевского \\ feddor70@mail.ru
}

Аннотация: В данной статье на основе архивных материалов Центрального архива Нижегородской области (ЦАНО) рассматриваются вопросы об особенностях проблемы недопоставок продовольствия и фуража в ходе формирования подразделений нижегородского ополчения в эпоху 1812 г. На основе делопроизводственной документации приводятся сведения о количестве недопоставленного продовольствия, вкупе с данными о тех помещиках, с которыми были связаны проблемы в снабжении и обеспечении ополчения. Сделан вывод 0 непредумышленном характере этих недопоставок, причиной которых были либо неправильные, либо корректирующиеся в ходе сбора ополчения, изначальные расчеты.

Ключевые слова: Отечественная война 1812 г., нижегородское ополчение 1812 г., походный марш, оружие, снаряжение, продовольствие, фураж.

ского [21, с.98]. Конный полк ополчения возглавил действительный статский советник П.Ф. Козлов [22, с.115]. Среди полномочных структур, созданных специально для этой цели, особо выделялись, по своему значению и функциям, комитеты пожертвований [17, с.217] и вооружения [18, с.35]. Обмундирование [16, с.58], снаряжение [14, с.39] и даже вооружение [9, с.75] ополчений той поры осуществлялось за счет «отдатчиков ратников», т.е. помещиков $[13$, с.345], либо мещанских сообществ [10, с.67]. Все полки нижегородского ополчения входили в состав так называемого III ополченского округа (вместе с ополчениями казанским, вятским, симбирским, пензенским и костромским) под предводительством генераллейтенанта П.А. Толстого. Непосредственным начальником нижегородского ополчения являлся князь Г.А. Грузинский.

Следует отметить, что вопросы снабжения и обеспечения ополчения всем необходимым всегда оставались в сфере пристального внимания властей [5, с.71] и специально назначенных чиновников, которые даже после окончания активной фазы боевых действий ополчения, пребывавшего в заграничном походе, подвергали ревизии приходо-расходную документацию с целью выявления возможных недопоставок, которые и были обнару- 
жены.

В мае 1814 г., согласно данным казначея комитета пожертвований нижегородского ополчения Салманова, по результатам поверки приходных и расходных книг провиантских чиновников [23, л.10] ,которые регулярно присылались в комитет), оказалось, что «против назначенного к сбору числа воинов и поступления к провиантским чиновникам провианта должно быть в недоборе: муки 259 четвертей, 2 четверика, крупы 24 четверти, 2 четверика, 4 1 1/2 гарнца» [23, л.3]. «Не значилось в приеме» провианта на следующее количество ополченцев (по уездам): Нижегородскому - на 23 чел., Горбатовскому - на 19, Ардатовскому - на 114, Арзамасскому - на 130, Княгининскому - на 31, Лукояновскому - на 26, Васильскому - на 5, Сергачскому - на 58, Макарьевскому - на 23, Балахнинскому - на 4 и Семеновскому - на 2. Всего «недоимочного провианта» значилось на 435 человек [23, л.3].

Выявленный недобор провианта происходил, как правило, не от корысти помещиков, искавших себе личной выгоды и саботировавших необходимые поставки (поскольку за это можно было получить штраф на гораздо большую сумму, либо поплатиться дворянским патентом), а от не всегда верных, либо корректирующихся, по ходу сбора, расчетов по «раскладкам» в процессе создания ополчения: «по числу сему превосходит тот следуемый в прием из недобора провиант, сие от того происходит, что к провиантским чиновникам поступало от некоторых помещиков излишне (но излишки, поступившие по неправильным расчетам, как правило, отдатчикам не возвращали, а обращали в «добровольные пожертвования» - авт.) и принято чиновниками с таких отдатчиков, коих в раскладочных списках было не назначено (раскладочные списки тоже корректировались в ходе набора ополчения - авт.), а к тому еще одним из них, господином Блаватским, принято от полкового начальника на 13 воинов неизвестно чьих помещиков (подобное происходило, как правило, если у помещика были владения в нескольких уездах, или губерниях - авт.), от чего сделалось и несходствие в полагаемом недоборе, которые разрешатся посредством взыскания» $[23$, л.3].

Также по отчетам провиантских чиновников «на строевых Конного полку лошадей остается в недоборе фуража на 125 лошадей, полагая на каждую в три месяца овса по 4 четверти, 1 четверику и 8 гарнцов, сена по 45 пуд» $[23$, л.4]. В общей сумме, на всех принятых в ополчение лошадей фуражных недоимок приходилось: овса 527 четвертей, 2 четверика, 6 гарнцев; сена: 5625 пудов, и, в соответствии с расчетами, следовало «добрать» с уездов губернии: Нижегородского - на 28 лошадей, Ардатовского - на 13, Арзамасского - на 12, Княгининского - на 5, Лукояновского - на 23, Васильского - на 1, Сергачского - на 9, Макарьевского - на 3, Балахнинского - на 4 и
Семеновского - на 27 [23, л.4]. Особо указывалось, что: «на каких же помещиках вся означенная недоимка считаться долженствует, до того дойти здесь нет возможности (т.е. именно сейчас нет такой возможности, но все это будет выяснено позднее - авт.), ибо раскладка общего Собрания предводителей сделана была только по числу душ в каждом уезде за помещиками находящихся, а разделение определенного числа лошадей в уездах по участкам и точное назначение имений к отправлению сей повинности зависело от каждого предводителя (т.е. уездного предводителя дворянства - авт.) по местному положению» [23, л.3]. Несколько позднее, по составленной ведомости, «каких уездов помещики поставили фураж, против сего сделаются уже известны неплательщики на фураж, подъемных лошадей и на смазку телег совсем не поступило в приход ни к которому провиантскому чиновнику по раскладке Предводителей» [23, л.4], а именно: «Ардатовского уезда на 15 пар («подъемные», или тягловые лошади, предназначенные для перевозки грузов, указывались, порой, не в количестве голов, а в количестве пар, т.е. условной «тягловой единицы» для повозки - авт.), Арзамасского на 15, Лукояновского на 13 пар, да осталось в недоимке на одну пару Макарьевского уезда, на коих, на коих по положению следовало принять на двухмесячное продовольствие по 96 рублей на каждую пару» [23, л.4].

По распоряжению комитета пожертвований, натуральный провиантский и фуражный недоимочный сбор должен был быть «монетизирован», а «поелику сбор воинов...с помещичьих имений производим был господами Дворянским Предводителями» [23, л.4], то к каждому из них от комитета доставлялись ведомости, где должны были быть (предводителями дворянства - авт.) указаны конкретные лица с требованием, «чтоб благоволили чрез нижние земские суды взыскать без всякого послабления, как наискорее, вместо полагаемого трехмесячного провианта ... деньгами против тех цен, какие в сентябре месяце прошлого 1812 года на торгах в уездах их существовали и Губернскому Начальству были показаны ... » $[23$, л.5].

По сводной «именной» губернской ведомости «о недоимке провианта» (несколько позднее аналогичная ведомость было составлена и «о недоимке фуража») составленной по отчетам провиантских чиновников ополчения можно установить всех недоимщиков по уездам, с которых позднее взимали деньги за недобранный провиант (ведомость приводится в авторском варианте):

Нижегородского (уезда помещики - авт.):

К. Олсуфьева, В. Борисов, П. Гагарин, А. Дадианова, М. Корепин, А.Попов, Т. Петрова, А. Петрова, В. Петрова, Е. Толстая, Н. Хитров, Н. Хитрова, В. Чемезов, Я. Анисимов 
Горбатовского:

А. Бутурлина, А. Бравина, А. Жиленкова, М. Приклонский, И. Русинов, Н. Шереметев

\section{Арзамасского:}

П. Бабушкин, В. Бабушкина, В. Баженов, В. Васильев, А. Воскресенская, Д. Голицын, М. Жуков, Д. Жуков, М.Жедринская, А.Жемайлова, М.Жмакина, К.Полуяхтова, Н. Мустафина, Н. Муханов, Е. Митюнин, С. Мессинг, В. Макашев, Ф. Назарьев, А. Оболенский, М. Приклонский, В. Полуяхтов, Н. Путятин, В. Семичевская, В. Шитова, Д. Хвостов, П. Чемоданов, Т. Черкашенинов, К. Юрлова, Д. Юрлов, Е. Свищева, П. Михайлов

\section{Ардатовского:}

Т. Аблязова, П. Бабушкина, А. Бутурлина, Н. Веселовская, Е. Глухова, А. Горихвостова, И. Гессе, К. Жидкова, И. Кисленский, Г. Разумовская, Н. Репнин, Ступишина, Панчулидзева, Н. Салтыков, М. Челищева, Н. Шахаев, П. Юшков, Ф. Янов

\section{Лукояновского:}

А. Бутурлина, Н. Бутурлин, А. Бахметева, М. Быков, П. Гагарин, И. Кашкаров, Е. Кандаурова, Г. Повалишин, Г. Рюмин, А. Соловцов, М. Соловцова, И. Светлов, И. Ульянин, П. Юшков

\section{Макарьевского:}

В. Борисов, М. Воейков, П. Возницына, П. Демидов, Т. Кугушева, В. Племянников, А. Разладина, М. Толстая, Н. Яковлева,
Балахнинского:

\section{Е. Лебедев, Е. Теряева}

\section{Сергачского:}

И. Ахматов, Н. Арцыбашев, Д. Болтин, Н. Бахметев, П. Бартенева, П. Беистов, А. Бобоедов, П. Григорьев, А. Есипов, А. Кайсаров, Ф. Мосолов, А. Нармацкая, А. Развадовский, П. Сенерина, П. Холенев, А. Григорьев

\section{Княгининского:}

А. Гагарин, П. Демидов, Е. Зиновьева, И. Курапин, А. Лопухин, К. Племянникова, Н. Свистунов, Н. Хитров, Б. Черкасский, П. Жедринский

\section{Васильского:}

Е. Никулина, В. Орлов, К. Кроткова, К. Енгалычева,

\section{Семеновского:}

Е. Пантелеев, Г. Осоргин [23, л.20]

Сообщения «с мест» о постепенной выплате недоимок подтверждались сопроводительными документами: квитанциями, письмами (с подтверждением платежа от недоимщиков) в комитет пожертвований от уездных предводителей дворянства, извещения от нижних земских судов. Для наиболее «весомой» конечной отчетности были выписаны даже номера государственных ассигнаций, шедших в счет оплаты [23, л.87]. Следует отметить, что по итогам ревизии практически все «владельческие» недоимки были выплачены в казну.

\section{ЛИТЕРАТУРА}

1. Акимов Л.Н., Акимова Е.А., Николаев Д.А. К истории формирования нижегородского ополчения: сведения о болезнях офицеров в сентябре - декабре 1812 г.//История медицины. 2019. Т.6. №4. С.278-285

2. Грубов В.И., Николаев Д.А. Вопросы архивоведения и источниковедения в высшей школе//Отечественные архивы. 2018. №1. С.116-117

3. Грубов В.И., Николаев Д.А. Вопросы архивоведения и источниковедения в высшей школе//Отечественные архивы. 2019. №2. С.129-131

4. Дорофеев Ф.А., Николаев Д.А. Особенности формирования офицерского корпуса в нижегородском ополчении 1812 г.//Вопросы истории. 2020 . №1. C.121-128

5. Дорофеев Ф.А., Николаев Д.А. Из истории нижегородского ополчения 1812 г.: проблема сдачи избыточного вооружения//В сборнике: Столица и провинции: взаимоотношения центра и регионов в истории России. Материалы XI Всероссийской научной конференции с международным участием. Ответственный редактор В.В. Карпова. 2020. С. 71-74

6. Дорофеев Ф.А., Николаев Д.А. Формирование и походный марш 2-го полка нижегородского ополчения 1812 г. (сентябрь 1812 - апрель 1813 гг.)// Современная наука: актуальные проблемы теории и практики. Серия «Гуманитарные науки». 2020. № 5. С. 29-32

7. Дорофеев Ф.А., Николаев Д.А. Формирование и походный марш 4-го полка нижегородского ополчения 1812 г. (сентябрь 1812 - апрель 1813 ГГ.)//Современная наука: актуальные проблемы теории и практики. Серия «Гуманитарные науки». 2020. № 8-2. С. 8-11.

8. Дроздов Ф.Б., Николаев Д.А. Народное ополчение 1812 г. и общественный договор//Вестник Нижегородского университета им. Н.И. Лобачевского. 2012. №6 (3). C.95-99

9. Егоров Г.В., Николаев Д.А. Формирование «подвижного магазейна» по снабжению армии в Нижегородской губернии в 1812 г.//Гуманитарные и социально-экономические науки. 2017. №5 (96). С.95-98

10. Николаев Д.А. Добровольцы в нижегородском ополчении 1812 г.: исторические реалии и историографические мифы//Вестник Нижегородского университета им. Н.И.Лобачевского.2018. №2. С.67-77

11. Николаев Д.А. Заболеваемость офицеров нижегородского ополчения 1812 г. (по материалам официального делопроизводства начала XIX века)// 
Оборонно-промышленный комплекс России: исторический опыт и современные стратегии. Сборник материалов ІІ Всероссийской научно-практической конференции. 2017. С.96-99

12. Николаев Д.А. Как и чем вооружалось нижегородское ополчение в 1812 году//Военно-исторический журнал. 2019. №2. С.75-79

13. Николаев Д.А. Комплекс документов по вопросам продовольственного и вещевого обеспечения нижегородского ополчения 1812 г.//Торговля, купечество и таможенное дело в России в XVI - XIX вв. Сборник материалов Четвертой международной научной конференции. Редактор-составитель А.И. Раздорский. Редколлегия: В.Н. Беляева [и др.]. 2018. С.345-349

14. Николаев Д.А. Материалы официального делопроизводства по вопросам продовольственного и вещевого обеспечения нижегородского ополчения 1812 г.//Вопросы архивоведения и источниковедения в высшей школе. Сборник статей участников XVI Региональной научно-практической конференции. Под редакцией В.И. Грубова, А.А. Исакова. 2019. С.39-43

15. Николаев Д.А. Некоторые аспекты развития военного производства Нижегородской губернии в начале XIX века (на примере вооружения нижегородского ополчения 1812 г.)//0боронно-промышленный комплекс России: исторический опыт и современные стратегии. (борник материалов II Всероссийской научно-практической конференции. 2017. С.58-62

16. Хвостова И.А., Николаев Д.А. Инспекторский смотр обмундирования и снаряжения нижегородского ополчения в 1812 г.//Современная наука: актуальные проблемы теории и практики. Серия «Гуманитарные науки». 2017. №12. С.58-61

17. Хвостова И.А., Николаев Д.А. Логистические особенности обеспечения нижегородского ополчения 1812 г. на начальном этапе его формирования (сентябрь - октябрь 1812 г.)//Вопросы истории. 2020. №2. С.217-224

18. Хвостова И.А., Николаев Д.А. Страницы истории нижегородского ополчения 1812 г.: проблема «лишнего» оружия//Современная наука: актуальные проблемы теории и практики. Серия «Гуманитарные науки». 2019. №9. С.35-37

19. Хвостова И.А., Николаев Д.А. «. . Упражняются. . . в пьянстве и буйстве. . .»: формирование и девиантные особенности походного марша 3-го полка нижегородского ополчения (сентябрь 1812 - июнь 1813 гг.)//История: факты и символы. 2019. №4 (21). С.27-36

20. Хвостова И.А., Николаев Д.А. Формирование и походный марш 1-го полка нижегородского ополчения 1812 г. (сентябрь 1812 - март 1813 гг.)//Современная наука: актуальные проблемы теории и практики. Серия «Гуманитарные науки». 2020. № 7-2. С. 19-22

21. Хвостова И.А., Николаев Д.А. Формирование и походный марш 5-го полка нижегородского ополчения 1812 г. (сентябрь 1812 - апрель 1813 гг.)//Гуманитарные и социально экономические науки. 2019. №3 (106). С.98-103

22. Хвостова И.А., Николаев Д.А. Формирование и походный марш конного полка нижегородского ополчения 1812 г. (сентябрь 1812 - февраль 1813 гг.)// Гуманитарные и социально экономические науки. 2018. №2 (99). С.115-119

23. Центральный архив Нижегородской области (ЦАНО), Ф.1822, 0п.1, Д.219

( ) Николаев Дмитрий Андреевич (dmnikolaeff@mail.ru), Дорофеев Федор Александрович (feddor70@mail.ru).

Журнал «Современная наука: актуальные проблемы теории и практики»

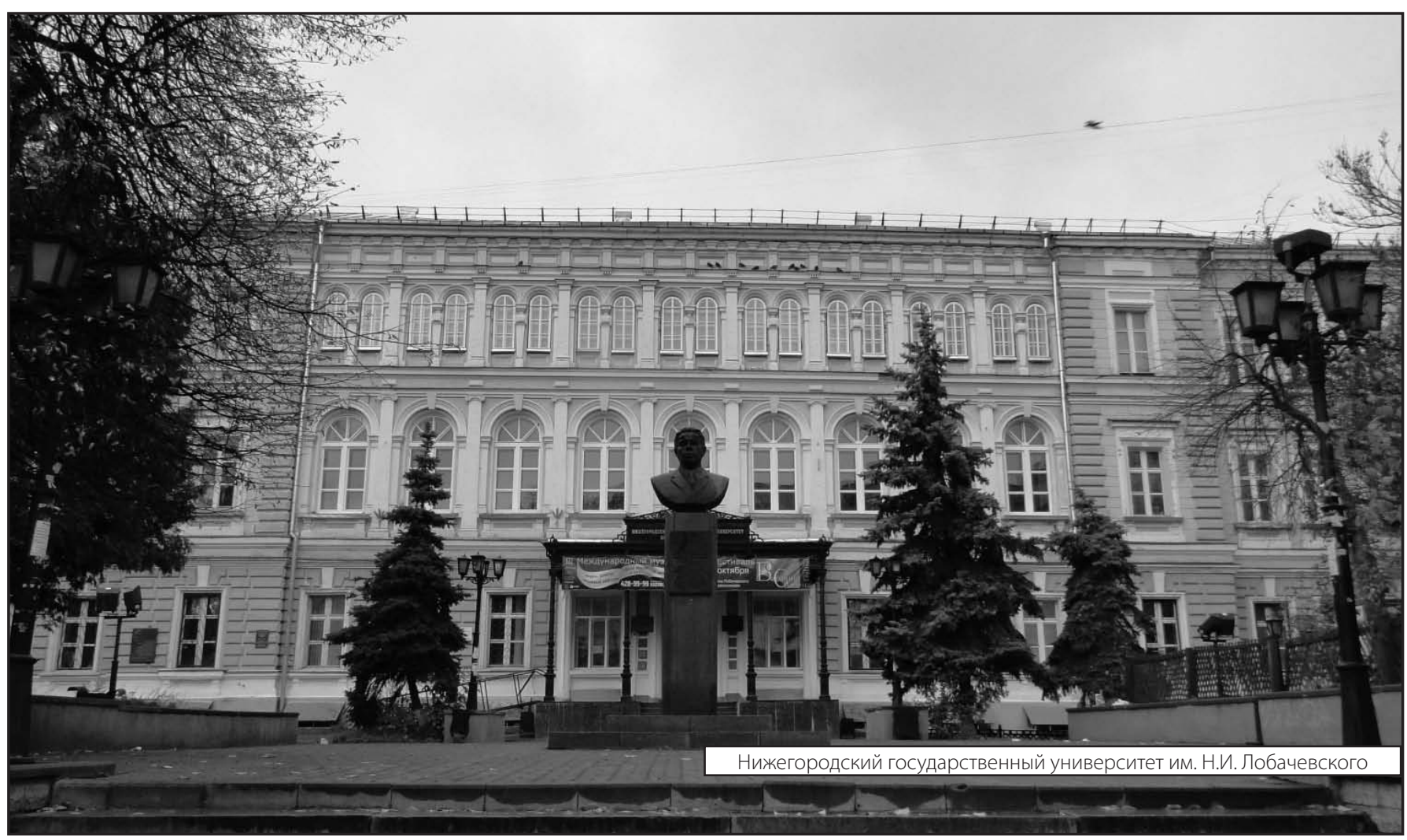

